\begin{tabular}{cc}
\hline JPPIPA, Vol.2 No.2 2017 \\
Jurnal Penelitian Pendidikan IPA
\end{tabular}

\title{
PENGEMBANGAN PERANGKAT PEMBELAJARAN INKUIRI UNTUK MENUNTASKAN HASIL BELAJAR SISWA PADA MATERI SISTEM ORGANISASI KEHIDUPAN
}

Oleh:

Fery Mayasari ${ }^{1}$, Raharjo ${ }^{2}$, Z.A. Imam Supardi ${ }^{3}$

1,2,3 Program Studi Pendidikan Sains, Program Pasca Sarjana, Universitas Negeri Surabaya, Surabaya 60231, Indonesia.

\begin{abstract}
Abstrak
Penelitian ini bertujuan untuk menghasilkan perangkat pembelajaran inkuiri yang layak untuk menuntaskan hasil belajar siswa pada materi sistem organisasi kehidupan. Jenis penelitian adalah penelitian pengembangan model Dick and Carey. Ujicoba perangkat pembelajaran dilakukan di SMP Negeri 4 Lamongan dengan menggunakan rancangan One Group Pretest-Posttest Design. Pengumpulan data menggunakan validasi, observasi, tes hasil belajar, pemberian angket, dan dokumentasi. Teknik analisis data dengan menggunakan deskriptif kuantitatif dan kualitatif. Hasil penelitian menunjukkan bahwa perangkat pembelajaran yang dikembangkan sangat valid sehingga dapat digunakan sebagai perangkat pembelajaran. Keterlaksanaan pembelajaran menunjukkan kategori baik, aktivitas siswa yang menonjol adalah melakukan pengamatan. Berdasarkan hasil analisis data dapat disimpulkan bahwa perangkat pembelajaran berbasis inkuiri tergolong layak (valid, praktis, dan efektif) digunakan pada materi sistem organisasi kehidupan pada siswa SMP.
\end{abstract}

Kata Kunci : Perangkat Pembelajaran, Model Pembelajaran Inkuiri, Hasil Belajar, Sistem Organisasi Kehidupan.

\begin{abstract}
This research aimed to produce set of teaching and learning material that feasible to mastery of student's learning achievement based on inquiry learning in junior high school students. Itconsist of syllabi, lesson plans, Studentbook, Student worksheets, Learning achievement test.Dick and Carey model was used to develop this learning material. It implementation to students of SMP 4 Lamongan. The collection data using validation, observation, learning achievement test, and questionnaire methods. Data were using quantitative and qualitative descriptive techniques.

The results showed that the developed learning materials were valid, practical, and affective to mastery of student's learning achievement. Based on the results, it be concluded that set of teaching and learning materials developedisfeasible to mastery of student's learning achievement on the material organization of life in junior high school.
\end{abstract}

Keywords: Learning Material, Inquiry Learning Model, Learning Achievement, Organization System of Life.

(C) 2017 Universitas Negeri Surabaya

${ }^{1}$ Alamat Korespondensi:

Program Studi Pendidikan Sains, Program

p-ISSN: $2527-7537$

Pasca Sarjana, Universitas Negeri Surabaya,

e-ISSN: 2549-2209

Surabaya 60231, Indonesia

Email: ferymayasari50@mhs.unesa.ac.id 


\section{PENDAHULUAN}

Kurikulum 2013 merupakan kurikulum pengembangan kompetensi peserta didik, yang menekankan pada penerapan pendekatan ilmiah (scientific approach) dalam proses pembelajaran. Pendekatan ilmiah dalam pembelajaran sebagaimana dimaksud meliputi: mengamati, menanya, mencoba, menalar dan mengomunikasikan untuk semua mata pelajaran (Kemendikbud, 2013e). Kurikulum 2013 menunjukkan adanya upaya penyederhanaan, dan tematik integrative yang mengacu pada KTSP. Kurikulum 2013 mendorong siswa untuk mampu melakukan observasi, bertanya, bernalar, mengomunikasikan yang diperoleh dan diketahui dalam proses pembelajaran. Hal ini sangat sesuai dengan pembelajaran IPA yang menekankan pada penemuan dalam mencari fakta-fakta, konsepkonsep dan prinsip dalam ilmu alam, tentunya jauh sebelum diterapkan kurikulum 2013 yang menekankan pada pendekatan saintifik, jauh sebelum itu pada Ilmu Pengetahuan Alam sudah mengenal langkah-langkah metode ilmiah. Sesuai dengan kurikulum 2013 yang menekankan pada pendekatan saintifik, peneliti sebagai guru IPA di SMP juga wajib menerapkan pembelajaran yang serupa yaitu pembelajaran yang menekankan pada penemuan untuk mencari fakta dan konsep guna memperoleh pengetahuan.

Berdasarkan Kurikulum 2013 yang baru mulai diterapkan di sekolah peneliti, maka peneliti tertarik untuk melakukan penelitian pada siswa kelas VII pada materi Sistem Organisasi Kehidupan karena materi tersebut peneliti anggap materi yang abstrak yang tidak dapat ditangkap oleh panca indera tanpa alat bantuan atau media, sehingga peneliti ingin mengajak para siswa untuk melihat seperti apa organisasi kehidupan yang dimulai dari tingkat sel yang hanya bisa dilihat dengan melalui mikroskop.

Peneliti sebelumnya mengawali kegiatan pra penelitian untuk mengetahui kemampuan pengetahuan siswa di SMP Negeri 4 Lamongan terhadap materi sistem organisasi kehidupan. Tes diberikan pada siswa IX E dengan jumlah 28 siswa. Siswa kelas IX yang dianggap sudah pernah mendapatkan materi tentang Sistem Organisasi Kehidupan diberikan soal tentang materi tersebut, dan di dapatkan hasil semua siswa mendapat nilai di bawah KKM dengan skor tertinggi adalah 67,5 dan skor rata-rata 36,63 dalam hal ini berarti semua siswa dinyatakan tidak tuntas (Kemendikbud, 2016). Hasil wawancara beberapa siswa yang dipilih secara acak menjelaskan bahwa materi pada Sistem Organisasi Kehidupan merupakan materi yang sulit karena mereka tidak pernah melihat sel secara langsung, mereka hanya melihat sel dari buku bacaan sehingga mereka mudah lupa dalam mengingat kembali materi tersebut. Selama ini guru lebih banyak menggunakan metode ceramah dan diskusi kelompok dalam materi Sistem
Organisasi Kehidupan dan siswa belum pernah diajak melakukan pengamatan dan pengalaman secara langsung pada materi tersebut.

Dari hasil pra penelitian, peneliti terdorong untuk berupaya menuntaskan hasil belajar di SMP Negeri 4 Lamongan pada materi Sistem Organisasi Kehidupan yang dilakukan dengan sengaja untuk mengetahui efek peserta terhadap hasil belajar pengetahuan, sikap dan keterampilan. Guru dapat mengamati perkembangan hasil belajar sikap dan keterampilan pada saat kegiatan pembelajaran berlangsung, sedangkan perkembangan hasil belajar pengetahuan dapat diketahui dari hasil pretest dan posttest.

Salah satu pembelajaran yang menekankan pada keaktifan siswa dalam proses pembelajaran adalah inkuiri. Strategi pembelajaran inkuiri juga sesuai dengan kurikulum 2013 yang menekankan pembelajaran dengan pendekatan saintifik. Inkuiri merupakan suatu proses untuk menjawab pertanyaan dan memecahkan masalah berdasarkan fakta dari hasil observasi.

Berdasarkan latar belakang tersebut, peneliti ingin melakukan penelitian Pengembangan Perangkat Pembelajaran Inkuiri yang diterapkan untuk menuntaskan hasil belajar siswa di SMP pada Materi Sistem Organisasi Kehidupan.

\section{METODE}

Penelitian ini merupakan penelitian pengembangan karena akan dikembangkan perangkat pembelajaran inkuiri pada materi Sistem Organisasi Kehidupan dengan model pengembangan Dick and Carey dengan desain penelitian One Group Pretest and Posttest Design.

Penelitian ini dilakukan di SMP Negeri 4 Lamongan pada semester Genap pada Tahun Pelajaran 2016/2017 tepatnya pada bulan Maret 2017. Subyek penelitian adalah Perangkat Pembelajaran Inkuiri pada Materi Sistem Organisasi kehidupan dengan sasaran uji coba siswa kelas VII.

Variabel dalam penelitian ini adalah validitas perangkat pembelajaran, keterlaksanaan RPP, aktivitas siswa, hasil belajar, dan respon siswa.

Teknik pengumpulan data dalam penelitian ini dengan menggunakan: validasi perangkat pembelajaran, observasi, tes hasil belajar, dan pemberian angket. Sedangkan instrumen penelitian yang digunakan dalam peneitian ini meliputi: lembar keefektivan siswa yang terdiri atas jurnal penilaian sikap, lembar penilaian tes hasil belajar siswa, lembar penilaian keterampilan siswa, dan lembar respon siswa.

Dalam penelitian ini data dianalisis dengan deskriptif analisis kuantitatif dan kualitatif yang meliputi analisis validasi perangkat pembelajaran, analisis kepraktisan perangkat pembelajaran, dan analisis keefektivan perangkat pembelajaran yang telah dikembangkan. 


\section{HASIL DAN PEMBAHASAN}

\section{Kevalidan Perangkat Pembelajaran}

Berdasarkan analisis kelayakan perangkat pembelajaran yaitu kevalidan, kepraktisan dan keefektivan perangkat pembelajaran. Maka diperoleh hasil sebagai berikut:

Analisis hasil validasi pengembangan perangkat pembelajaran diperoleh rata-rata skor validitas RPP untuk format 4.0, isi 3.9 bahasa 4.0, dan keseluruhan aspek dalam kategori RPP sangat valid (Ratumanan dan Laurens, 2011). Dengan kecocokan sebesar $98.4 \%$ sehingga dalam kategori cocok (Borich, 1995). Hasil validasi pada Bahan Ajar Siswa (BAS) diperoleh skor rata-rata untuk isi 3.7, bahasa 3.7 , penyajian materi 3.6, dan keseluruhan aspek dengan kategori sangat valid (Ratumanan dan Laurens, 2011) dengan persentase kecocokan dari kedua validator sebesar 97\% dengan kategori cocok (Borich, 1994). Hasil validasi pada Lembar Kegiatan Siswa (LKS) diperoleh skor rata-rata untuk format 3.4, bahasa 3.6, isi 3.6 dan keseluruhan aspek dengan kategori sangat vaid (Ratumanan dan laurens, 2011) dengan kecocokan 96\% (Borich, 1995). Pada hasil validasi pada Tes Hasil Belajar (THB) diperoleh rata-rata skor pada soal pilihan ganda diperoleh validasi isi sebesar 4.0, validitas bahasa sebesar 3.3, sedangkan pada soal uraian diperoleh validitas isi sebesar 4.0 dan validitas bahasa sebesar 3.5. Hal ini menunjukkan bahwa validitas Tes Hasil Belajar bisa digunakan tanpa ada revisi.

\section{Kepraktisan Perangkat Pembelajaran}

Analisis kepraktisan dengan menerapkan perangkat pembelajaran yang telah dikembangkan meliputi analisis keterlaksanaan RPP dan analisis keaktivan siswa. Berdasarkan hasil pengamatan oleh dua orang pengamat maka dihasilkan keterlaksanaan RPP sebagai berikut:

\section{Lesson Plan Implementation Result}

口Introdution $\square$ Main Activity $\square$ Closing

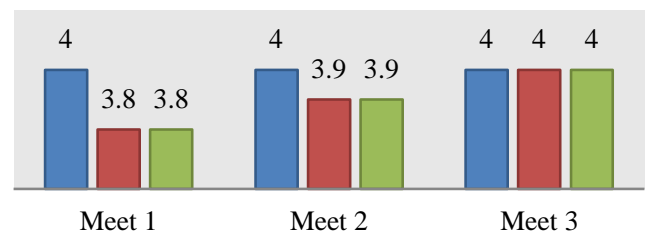

Gambar 1. Hasil Keterlaksanaan RPP

Berdasarkan grafik di atas dapat dianalisis bahwa keterlaksanaan RPP dengan menggunakan perangkat pembelajaran yang telah dikembangkan pada setiap sintaks menunjukkan adanya peningkata dalam setiap pertemuan dengan diperoleh nilai rata-rata 3.9 dengan kategori baik (Ratumanan dan Laurens, 2011).

Pada aspek keaktifan siswa dalam pembelajaran sebanyak tiga kali pertemuan dapat digambarkan dalam diagram sebagai berikut:

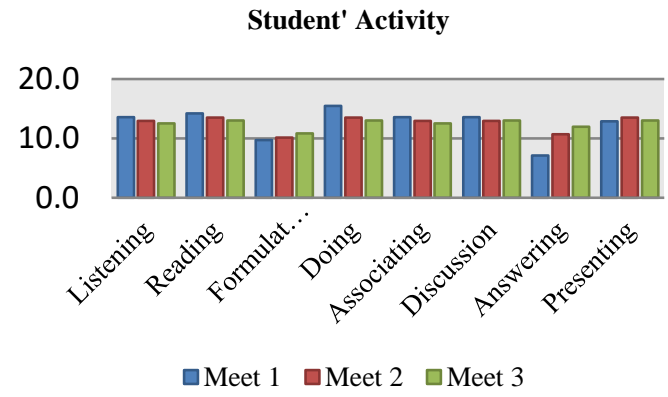

Gambar 2. Hasil Keaktifan Siswa

Berdasarkan grafik di atas diperoleh informasi kegiatan siswa dalam aktivitas pembelajaran yang tertinggi adalah dalam melakukan pengamatan dengan persentase sebesar $14.0 \%$, dan persentase terendah adalah dalam menjawab pertanyaan guru sebesar $9.9 \%$.

Analisis kefektivan penerapan perangkat pembelajaran meliputi analisis sikap, analisis hasil belajar pengetahuan, analisis hasil belajar keterampilan dan respon siswa terhadap pembelajaran dengan diterapkan perangkat pembelajaran yang telah dikembangkan.

Analisis sikap selama pembelajaran digunakan untuk mengetahui perkembangan sikap siswa selama pembelajaran berlangsung dan memfasilitasi tumbuhnya perilaku siswa. Adapun perkembangan sikap siswa yang dipelajari selama KBM difokuskan pada nilai karakter jujur, bertanggung jawab dan percaya diri yang dicatat dalam jurnal penilaian sikap.

\section{Kefektivan Perangkat Pembelajaran}

Analisis hasil belajar pengetahuan siswa dapat dilihat dalam diagram berikut. 


\section{Hasil Belajar Siswa}

$\square$ Pre-Test $\square$ Post-Test

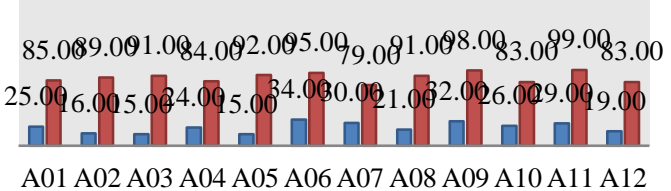

Gambar 3. Hasil Belajar Siswa

Berdasarkan diagram di atas maka dapat diketahui bahwa sebelum dilakukan penerapan perangkat pembelajaran yang dikembangkan diperoleh hasil pretest rata-rata sebesar 23.83 sedangkan setelah diterapkan perangkat pembelajaran yang telah dikembangkan diperoleh hasil posttest dengan rata-rata 89.08 dengan kategori tuntas. Jika telah ditetapkan bahwa nilai ketuntasan minimal siswa adalah 70 .

\section{SIMPULAN DAN SARAN}

\section{Simpulan}

Kesimpulan dari penelitian ini adalah telah dihasilkan perangkat pembelajaran yang layak dalam menuntaskan hasil belajar siswa pada materi Sistem Organisasi Kehidupan pada siswa SMP di SMP Negeri 4 Lamongan.

\section{Saran}

Berdasarkan penelitian yang telah peneliti

1. Perangkat pembelajaran inkuiri yang dikembangkan oleh peneliti dinyatakan layak dan dapat menuntaskan hasil belajar siswa, sehingga diharapkan adanya penelitian lanjutan guna mengembangkan pemahaman konsep/ materi siswa supaya lebih mendalam berasal dari pelajaran penemuan.

2. Perlu dilakukan penelitian serupa untuk membiasakan siswa agar terampil dalam membuat rumusan pertanyaan/masalah pada pembelajaran inkuiri.

3. Untuk lebih sempurnanya perangkat pembelajaran yang dikembangkan dalam menuntaskan hasil belajar siswa, perlu dilakukan penelitian serupa pada pokok bahasan yang sama.

\section{DAFTAR PUSTAKA}

Arends, I. Richard. (1997). Learning to teach. New York: Mc. Graw Hill Companies, Inc

Borich, G. (1994). Observation Skills for Effective Teaching. New York: MacMillan Publishing Company.
Dick, W., Carey, L., \& Carey, L. (2009). The Systematic Design Instruction. Columbus: Pearson Education.

Dimyati,.\& Mujiono. (2009). Belajar \& Pembelajaran. Jakarta: Rineka Cipta

Eggen, P., \& Kauchak, D. (2012). Strategi dan Model Pembelajaran. Jakarta: Indeks.

Hake. (1999). Analyzing change/gain score (online). Retrieved September 2016, from http://www.physics.indiana.edu/sdi/Analyz ingChange-Gain.pdf.

Ibrahim, M. (2005). Asesmen Berkelanjutan Konsep Dasar, Tahapan Pengembangan dan Contoh. Surabaya: Unesa Press.

Ibrahim, M. (2014). Inovasi Pendidikan Sains dalam Menyongsong Pelaksanaan Kurikulum 2013. Seminar Nasional Pendidikan Sains Pascasarjana, pp 1-12. Surabaya: PPS Unesa.

Joyce, B., Weil, M., \& Calhoun, E. (2009). Models of Teaching Model-model Pengajaran. Yogyakarta: Pustaka Pelajar.

Kardi, S. (2013). Model Pengajaran Langsung, Inkuiri, Sains Teknologi Masyarakat. Surabaya: PPS Unesa.

Kardi, S. (2012). Pengantar Pengembangan Kurikulum dan Rencana Pelaksanaan Pembelajaran. Surabaya: PPS Unesa.

Kermendikbud. (2016). Permendikbud Nomor 23 Tahun 2016 Tentang Standart Penilaian Pendidikan. Jakarta: Kemendikbud.

Kermendikbud. (2016). Permendikbud Nomor 24 Tahun 2016 Tentang Kompetensi Inti dan Kompetensi Dasar Pelajaran Pada Kuirkulum 2013 Pada Pendidikan Dasar dan Pendidikan Menengah. Jakarta: Kemendikbud.

Kusrianto, A \& Martadinata, Y. (2015). Microsoft Word untuk Bahan Ajar. Jakarta: Kompas Gramedia

Nur, M. (2008). Pemotivasian Siswa Untuk Belajar. Surabaya: Universitas Negeri Surabaya.

Nur, M. (2008a). Pengajaran Berpusat Kepada Siswa dan Pendekatan Kontruktivis dalam Pengajaran Edisi 5. Surabaya: Universitas Negeri Surabaya.

Ratumanan, G., \& Laurent, T. (2011). Penilaian Hasil Belajar pada Satuan Pendidikan Tingat Pendidikan edisi kedua. Bandung: Alfabeta.

Riduwan. (2003). Skala Pengukuran Variabelvariabel Penelitian. Bandung: Alfabeta.

Sanjaya, W. (2010). Strategi Pembelajaran Berorientasi Standart Proses Pendidikan. Jakarta: Prenada Media Grup.

Sudjana. (2011). Penilaian Hasil Belajar Mengajar. Bandung: Rosdakarya. 
Fery Mayasari, Raharjo, Z.A. Imam Supardi, JPPIPA (Jurnal Penelitian Pendidikan IPA), 2017, Vol. 2, No. 2, 53-57

Sugiyono. (2015). Metode Penelitian Pendidikan.

Bandung: Alfabet. 